\title{
Maternal and Child Care Assessment Focused on Prenatal Care and Birth
}

\author{
Isabelle Christine Fonsêca G. A. Silva1, \\ Tainara Lôrena dos Santos Ferreira1, Dídia de Oliveira Pereira1, \\ Joymara Railma Gomes de Assunção' ${ }^{1}$, Paloma Batista Costa ${ }^{1}$, \\ Jovanka Bittencourt Leite de Carvalho², Iris do Ceu Clara Costa ${ }^{3}$, \\ Fábia Barbosa de Andrade ${ }^{1}$
}

\footnotetext{
${ }^{1}$ Nursing, Faculty of Health Sciences of Trairi (FACISA), Federal University of Rio Grande do Norte (UFRN), Santa Cruz, Brazil

${ }^{2}$ Department of Nursing, Federal University of Rio Grande do Norte (UFRN), Natal, Brazil

${ }^{3}$ Department of Dentistry, Federal University of Rio Grande do Norte (UFRN), Natal, Brazil

Email: isabellefonseca1@hotmail.com, tainara lorena@hotmail.com, didia oliveira@hotmail.com, railmas@hotmail.com, paloma_acd@hotmail.com, jovanka@ufrnet.br, iris odontoufrn@yahoo.com.br, fabiabarbosabr@yahoo.com.br
}

Received 19 December 2014; accepted 21 January 2015; published 30 January 2015

Copyright (C) 2015 by authors and Scientific Research Publishing Inc.

This work is licensed under the Creative Commons Attribution International License (CC BY). http://creativecommons.org/licenses/by/4.0/

(c) (i) Open Access

\section{Abstract}

Objective: This study aims at assessing maternal and child care provided from prenatal to birth, so that it can reveal the weaknesses and potentialities of prenatal program in order to guide the development of strategic plans. Methods: This is an exploratory descriptive study with a quantitative approach, conducted in the city of Santa Cruz, state of Rio Grande do Norte, Brazil, from November 2012 to February 2013. The sample consisted of 200 women, chosen by draw, mothers of children under two years old who had attended the Primary Health Care System. The study used a semistructured questionnaire used by the Ministry of Health. Our research project was approved by the Research Ethics Committee of the Federal University of Rio Grande do Norte, under the approval No. 311.613. Results: It was found that most mothers were rated from good to very good in the quality of care during prenatal and birth. As to the performance of prenatal and birth care services, most women performed those services under the municipality's Public Health System, and the prenatal care primarily under Basic Health Care Units. Conclusion: In this assessment study, indicators regarding maternal and child care provided during the prenatal period were found to be positive, which contributes to the reduction of maternal and child mortality. The study also shows that Primary Health Care is essential to ensuring an effective, humane and comprehensive health care. 
Keywords

Primary Health Care, Health Assessment, Nursing

\section{Introduction}

Medical care during pregnancy occurs through a set of clinical and educative processes that aim at promoting health and precociously identifying problems that can put the pregnant and embryo's health at risk. Thus, a quality medical care is the one that guides and sheds light on the birth process and also on the newborn's care, with the objective to reduce the rates of maternal-infantile morbid-mortality.

Pregnancy and birth are physiological events that promote physical and emotional changes in women, requiring family and health professionals' care through prenatal care [1].

Prenatal care must accompany the entire pregnancy, so that it can promote the birth of a healthy child, and ensure mother and child's welfare. In order to provide a quality care, it is necessary to adopt a welcoming behavior and actions for the pregnant woman and fetus' health promotion, prevention and care, from the basic ambulatory care to the hospital high-risk care, if necessary [2].

It is essential to provide a quality care, identifying pregnancy risks during the anamnesis and clinical examination. If necessary, measures shall be considered in order to mitigate complications for mother and fetus. Thus, therapeutic interventions, for example, are suggested to prevent overweight and obesity. Pregnant women shall be counseled about the importance of physical activity and nutritional aspects in order to prevent and/or reduce the body weight gain [3].

In this sense, quality care involves health care team actions focused on multidisciplinary and problem-solving skills to identify pregnancy risk's signs and symptoms. In Brazil, the health care model is focused on the primary system, more specifically, on the Primary Health Care (PHC), also known as Basic Health Care. PHC is regulated by a Ministerial Decree that guides and conducts the health care actions as well as professional skills for each health program. In this context, prenatal care is a health program proposed by the Ministry of Health to be implemented in the PHC system.

Prenatal care begins in the PHC by a multidisciplinary team based on actions for health promotion, protection and disease prevention. This team consists of a physician, a nurse, a nurse assistant or technician and community health agents, and may be increased by adding one dental surgeon plus an assistant or technician in oral health [4].

Nurse and physician shall provide prenatal care through specific medical consultations, considering that at this moment a care plan is traced in order to identify priorities, develop interventions, guidance and referrals to other services. Prenatal care is not a technical procedure centered on a biological phenomenon, but rather a moment in which a link is established, as well as hosting, security and confidence, also strengthening the nurse/ pregnant and physician/pregnant relationships, so that these professionals can use their sensitivity to contemplate the patient as a biopsychosocial being, someone who has had a particular history before a medical history [1].

Prevention undertaken by a multidisciplinary team and a good metabolic control before and during pregnancy, provide control of inadequate weight gain and contribute decisively to the improvement of high-risk pregnancies obstetric prognosis [5].

The appropriate maternal weight gain is an essential factor for a successful pregnancy development, and also for the mother and child's health preservation in the long term. Maternal obesity and weight gain above indicated rates increase the risk of many undesirable outcomes, such as: gestational diabetes, hypertension in pregnancy and prolonged labor.

That said, this study seeks to measure the quality of health care actions provided during prenatal care and birth in order to reveal its strengths and weaknesses, as well as to lead health care managers in developing the strategic health planning. Thus, this study's objective is to assess the maternal and child care in Primary Health Care.

\section{Methodology}

This is a quantitative and evaluative research conducted in Basic Health Units (BHU) within the Primary Health 
Care (PHC) system, at the city of Santa Cruz, state of Rio Grande do Norte, Brazil, the period of November 2012 to February 2013. Data collection was conducted with 200 women, mothers of children under two years old, who attended the PHC system.

The present work is a clipping of the research entitled Maternal and child morbidity and mortality: an assessment study on Primary Health Care. Data collection was performed using a semi-structured questionnaire used by the Ministry of Health. Health care facilities and research subjects were chosen by draw. In order to participate in the study these inclusion criteria were observed: mothers needed to be over 18 years old and mothers of children aged less than two years, they should have received prenatal care in the drawn unit, and needed to present the cognitive ability to answer questions and sign the Term of Free Informed Consent (TFIC).

The results had been analyzed and incorporated into Stata 9.0 software. Calculating the mean, median and standard deviation, variance and chi-square test were performed with significance level values below 0.05 and a confidence interval of $95 \%$.

This study followed the recommendations contained in Resolution 466/2012 of the National Health Council, regarding research with human subjects. This study was approved by the Ethics and Research Committee (ERC) at the Faculty of Health Sciences of Trairi (FACISA), under the approval No. 311.613.

\section{Results}

This study has surveyed 200 mothers (100\%).

As shown in Table 1, mothers' mean education was 4.0 years of study, median of 5.0 years, standard deviation of 3.29, and as for age was obtained average 29.06, median 28.0, and standard deviation 7.47. Regarding the prenatal care, it was observed that $95.5 \%(\mathrm{n}=191)$ of mothers reported they have attended prenatal care services, while $4.5 \%(n=09)$ of mothers have not.

Table 2 presents the rates of quality of care during prenatal and birth from the users' point of view, in this case, the mothers'. Therefore, as to the quality of care provided by professional staff in conducting prenatal care, $60.5 \%(n=121)$ of mothers rated it as good, followed by $27.0 \%(n=54)$ of mothers who rated it as very good. With regard to the quality of care during childbirth, it was found that $61.1 \%(\mathrm{n}=121)$ of mothers considered it as good and $27.3 \%(n=54)$ of them rated it as very good.

Regarding the health service in which the prenatal care was performed, it was found that $91.0 \%(n=182)$ of mothers used public health services in their own municipality; 3.0\% $(n=06)$ of them used private health services. Thus, it was observed a correlation between the quality of care provided during prenatal and the health service in which the prenatal care was performed, as it was obtained a p-value $=0.000$ in the chi-square test.

Regarding the place where the prenatal care was performed, it was found that $73.5 \%(\mathrm{n}=147)$ of mothers conducted it in a Basic Health Unit (BHU), followed by $18.0 \%(n=36)$ who underwent prenatal care in hospitals. Thus, there was a correlation between the quality of care provided during prenatal and the health service facility where it was performed.

With regard to the correlation of variables: quality of care in prenatal care and the performance of some procedures such as measuring blood pressure, showed that 93.0\% $(n=186)$ of mothers had their blood pressure measured at every visit and 4.5\% $(n=09)$ of them reported having their blood pressure measured in just a few visits.

As for checking the weight during the prenatal consultations, it was found that $95.0 \%(\mathrm{n}=190)$ of mothers indicated having performed this procedure during all visits; and 3.0\% $(n=06)$ in only a few visits. The chi-square test $\mathrm{p}$-value was $\mathrm{p}=0.000$, which means, therefore, a significant association between the quality of prenatal care, the measurement of blood pressure and weight.

In Table 5, concerning the place where the birth care was performed, it was observed that $87.0 \%(n=174)$ of mothers held childbirth in a public hospital in their own municipality's Public Health System; followed by $8.0 \%$ $(n=16)$ who held it in a public hospital in another municipality's Public Health System. It was noticed a correlation between the quality of care at birth and the place where mothers held childbirth by obtaining a p-value $<5 \%$ in the chi-square test.

Regarding the combination of variables: quality of care provided during birth and breastfeeding in the first hour following birth, the results showed that $65.5 \%(n=131)$ of mothers reported having breastfed the newborn in his/her first hour of life and 34.5\% $(n=69)$ of them said they did not breastfeed their babies. Regarding this data, the chi-square test $\mathrm{p}$-value was $\mathrm{p}=0.164$, which means, therefore, no significant association between 
variables, as it presented a p-value $>5 \%$.

\section{Discussions}

In this study, it was observed a potential correlation between the mothers' rating regarding the quality of care during prenatal care in the PHC system. In Table 1, mothers' mean education was 4.0 years of study, median of 5.0 years, standard deviation of 3.29. And as for age was 29.06 Obtained average, median 28.0, standard deviation and 7:47. This reveals a low education, which may reflect the quality of preventive health. According to Table 2, the rating of prenatal care provided in the PHC was reported as good from the viewpoint of respondents. This comes from the certainty of knowing how the assistance has been conducted, which competes for achieving improvements in the health service focusing on continuity and comprehensiveness of care actions. To understand the Public Health System's weaknesses in the user perception is very important for its effectiveness, as it shall boost the search for problem solving.

The user role as the protagonist of the health care system has a direct impact on improving the relationship between him and the health service. Thus, it is important to know how users assess the care provided to them, so that we can rethink professional practices, or intervene on health services' organization form, aiming at its improvement [6].

As shown in Table 3, prenatal care of interviewed mothers have been conducted primarily in public health services in their own municipality, which indicates that accessibility is given in accordance with what has been recommended by the Ministry of Health.

Referring to Table 4, it is known that primary health care is presented as the first level of care and consists of

Table 1. Socio-demographic information of the respondents. Santa Cruz, RN, Brazil, 2013.

\begin{tabular}{cccc}
\hline Variables & Mean & Median & Std. deviation \\
Education-years studied & 4.0 & 5.0 & 3.29 \\
Age & 29.06 & 28.0 & 7.47 \\
\hline
\end{tabular}

Table 2. Quality of care during prenatal and birth rating from the users’ point of view. Santa Cruz, RN, Brazil, 2013.

\begin{tabular}{|c|c|c|c|c|c|c|}
\hline Variables & Very good & Good & Fair & Bad & Very bad & Total \\
\hline Quality of prenatal care & $\begin{array}{c}27.0 \% \\
(n=54)\end{array}$ & $\begin{array}{c}60.5 \% \\
(n=121)\end{array}$ & $\begin{array}{c}8.5 \% \\
(n=17)\end{array}$ & $\begin{array}{c}1.0 \% \\
(\mathrm{n}=02)\end{array}$ & $\begin{array}{c}1.0 \% \\
(\mathrm{n}=02)\end{array}$ & $\begin{array}{c}100.0 \% \\
(n=200)\end{array}$ \\
\hline Quality of care during childbirth & $\begin{array}{c}27.3 \% \\
(n=54)\end{array}$ & $\begin{array}{c}61.1 \% \\
(\mathrm{n}=121)\end{array}$ & $\begin{array}{c}4.5 \% \\
(n=09)\end{array}$ & $\begin{array}{c}3.5 \% \\
(n=07)\end{array}$ & $\begin{array}{c}3.5 \% \\
(\mathrm{n}=07)\end{array}$ & $\begin{array}{c}100.0 \% \\
(n=200)\end{array}$ \\
\hline
\end{tabular}

Table 3. Correlation between the quality of care provided during prenatal and the health service in which the prenatal care was performed. Santa Cruz, RN, Brazil, 2013.

\begin{tabular}{ccccc}
\hline \multicolumn{1}{c|}{ Variables } & $\begin{array}{c}\text { Public Health Service } \\
\text { in their municipality }\end{array}$ & $\begin{array}{c}\text { Public Health Service } \\
\text { in another municipality }\end{array}$ & $\begin{array}{c}\text { Private Health/Health } \\
\text { Insurance/Health Plan } \\
\text { Services }\end{array}$ & $\begin{array}{c}\text { Private Health } \\
\text { Services }\end{array}$ \\
p-value \\
$\begin{array}{c}\text { Health Service in which the } \\
\text { prenatal care was performed }\end{array}$ & $\begin{array}{c}91.0 \% \\
(\mathrm{n}=182)\end{array}$ & $\begin{array}{c}2.5 \% \\
(\mathrm{n}=05)\end{array}$ & $\begin{array}{c}8.5 \% \\
(\mathrm{n}=17)\end{array}$ & 0.000 \\
\hline
\end{tabular}

Table 4. Correlation between the quality of care provided during prenatal and the health service facility where the prenatal care was performed.

\begin{tabular}{ccccc}
\hline Variables & Basic Health Unit & Hospital & Private office & Specialty clinic \\
\hline $\begin{array}{c}\text { Health Service Facility } \\
\begin{array}{c}\text { where the prenatal care } \\
\text { was performed }\end{array}\end{array}$ & $\begin{array}{c}73.5 \% \\
(\mathrm{n}=147)\end{array}$ & $\begin{array}{c}18.0 \% \\
(\mathrm{n}=36)\end{array}$ & $\begin{array}{c}3.5 \% \\
(\mathrm{n}=07)\end{array}$ & $\begin{array}{c}1.5 \% \\
(\mathrm{n}=03)\end{array}$ \\
\hline
\end{tabular}


a comprehensive and continuous care, which enables the identification of risk factors and frequent pregnancy complications. Thus, it is perceived the importance of performing prenatal care in health units within the PHC system, with a view to reducing maternal and child morbidity and mortality.

The most important actions regarding maternal mortality control depend on the access and quality of care performed by health services, particularly during birth and postpartum care [7]. The quality of health care services for pregnant women cannot be effective without considering their needs and/or expectations and without being sensitive and intuitive to capture what needs to be included in the woman's care plan, making her feel comfortable and tranquil [8].

As for the performance of recommended clinical and obstetric procedures during prenatal care, such as the measurement of Blood Pressure (BP) and weight, which can precociously detect hypertensive and diabetic conditions, evaluation of weight gain during pregnancy and nutritional status, it was observed a positive percentage of these variables thereby proving that health professionals are promoting adequate care.

The monitoring of blood pressure shall be assessed together with the sudden weight gain and/or edema presence, mainly from the 24th week on. Women whose weight gain exceed $500 \mathrm{~g}$ per week, even without increasing blood pressure, shall return to the physician beforehand, considering the increased risk of preeclampsia [9].

In regards to the place where the childbirth (Table 5) was performed, it was realized that as to the care provided to women, some of them held birth in a public hospital in their own municipality's Public Health System, and others in a public hospital in another municipality. Thus, it is necessary to ensure the coordination of services as different places regarding the performance of prenatal care were presented, and since all health services system shall seek for the resolution of needs along with a continuous care provided in primary health care, so that the individual is holistically perceived and all necessary health care is provided.

With regards to breastfeeding within the first hour following birth, it is known that this is of fundamental importance to the mother-child binomial, as it stimulates the growth and development of children, in addition to strengthening the emotional bond between child and mother. Importantly, although the majority of users claimed to have breastfed their babies within the first hour of life, the respondents who said they had not breastfed their babies have demonstrated the need for promoting breastfeeding in the first hour after birth.

It is necessary that mothers are empowered to breastfeed still in the delivery room, so that their characteristics and socio-cultural diversities are respected. The woman shall be the subject in the act of breastfeeding in the first hour of life. This shall not be a procedure to which the woman is subjected towards an ideal of humanization. The empowerment shall begin prenatally, from the dialogue between the healthcare team and women about all breastfeeding potentials and benefits during the first hour of life, so that women can assess and build their own choices [10].

In the early days, breast milk is essential to promote a deep interaction between mother and child, as well as its impact on the children nutritional status, on their ability to fend off infections, their physiology, their cognitive and emotional development, as well as on implications for the mother's physical and mental health. Breastfeeding shall be the sole source of nutrition up to six months of life and can be extended along with other foods until the child is two years old [11].

This shows the need of health care team performance in providing quality care. For, as we know, health professionals play an important role in the care of women during pregnancy and childbirth insofar as they make them feel welcome and recognized in the process of pregnancy monitoring, a factor that benefits the women and child's health [12].

Therefore, the study conducted here revealed high coverage, however the use of health services was uneven. On the other hand, mothers with lower income and who, at a greater proportion, had not planned the pregnancy,

Table 5. Correlation between the qualities of care provided during birth and the health service facility where the birth care was performed. Santa Cruz, RN, Brazil, 2013.

\begin{tabular}{|c|c|c|c|c|c|c|}
\hline & $\begin{array}{c}\text { Public Hospital in their } \\
\text { municipality’s Public } \\
\text { Health System }\end{array}$ & $\begin{array}{c}\text { Public Hospital in } \\
\text { another municipality’s } \\
\text { Public Health System }\end{array}$ & $\begin{array}{c}\text { Private Hospital } \\
\text { (Health Plan/Insurance) }\end{array}$ & $\begin{array}{l}\text { Private } \\
\text { Hospital }\end{array}$ & Home care & p-value \\
\hline $\begin{array}{c}\text { Health Service Facility } \\
\text { where the birth care } \\
\text { was performed }\end{array}$ & $\begin{array}{c}87.0 \% \\
(n=174)\end{array}$ & $\begin{array}{c}8.0 \% \\
(n=16)\end{array}$ & $\begin{array}{c}1.0 \% \\
(\mathrm{n}=02)\end{array}$ & $\begin{array}{c}1.5 \% \\
(\mathrm{n}=03)\end{array}$ & $\begin{array}{c}1.0 \% \\
(\mathrm{n}=02)\end{array}$ & 0.013 \\
\hline
\end{tabular}


were the ones who initiated prenatal care later and the ones that least attended medical consultations during pregnancy. Remember that this is also the group of women that most used public services for prenatal, birth and newborn monitoring [13].

\section{Conclusions}

In this assessment study, the indicators showed positive results concerning the quality of prenatal care held at the PHC system and births performed in referral maternities. This data reveal to Brazil that the established target was achieved, which is the provision of prenatal consultations in PHC with minimum of 7 consultations, interspersed between physician and nurse.

The results obtained meet the actions recommended by the Pact for Life and the Pact for reduction of maternal and child mortality, defined as the implementation of diseases and complications preventive actions, which are presupposed in the quality actions performed on the PHC. There were limitations of the study as the noninclusion of all social actors and different perspectives to assess the care model developed; and be a local study, however, the municipality has the same reality with other cities in the country.

This shows the need for reducing complications and problems that may occur at the time of labor performed in public services within municipalities' public health system, which reflects the need of qualified performance of professionals involved in maternal and child care services provided in each region’s PHC system.

\section{References}

[1] Duarte, S.J.H. and Andrade, S.M.O. (2006) Assistência pré-natal no Programa Saúde da Família. Esc Anna Nery R Enfer, 10, 121-125. [Online] http://www.scielo.br/pdf/ean/v10n1/v10n1a16.pdf

[2] Brasil. Ministério da Saúde. Secretaria de Atenção à Saúde. Departamento de Ações Programáticas Estratégicas (2005) Pré-natal e puerpério: Atenção qualificada e humanizada-Manual técnico. Brasília.

http://bvsms.saude.gov.br/bvs/publicacoes/manual_pre_natal_puerperio_3ed.pdf

[3] Assis, T.R., Viana, F.P. and Rassi, S. (2008) Estudo dos principais fatores de risco maternos nas síndromes hipertensivas da gestação. Arquivos Brasileiros de Cardiologia, 91. http://www.scielo.br/scielo.php?script=sci_arttext\&pid=S0066-782X2008001300002\&lng=en\&nrm=iso

[4] Brasil. Ministério da Saúde. Política Nacional de Atenção Básica. Departamento de Atenção Básica. Brasília, 2012. http://189.28.128.100/dab/docs/publicacoes/geral/pnab.pdf

[5] Fernandes, R.S.R., et al. (2012) Prognóstico obstétrico de pac ientes portadoras de diabetes mellitus pré-gestacional. Revista Brasileira de Ginecologia e Obstetrícia, 34.

http://www.scielo.br/scielo.php?script=sci arttext\&pid=S0100-72032012001100003\&lng=en\&nrm=iso. http://dx.doi.org/10.1590/S0100-72032012001100003

[6] Ramos, D.D. and Lima, M.A.D.S. (2003) Acesso e acolhimento aos usuários em uma unidade de saúde de Porto Alegre, Rio Grande do Sul, Brasil. Cadernos de Saúde Pública, Rio de Janeiro, 19, 27-34. http://www.scielosp.org/pdf/csp/v19n1/14902.pdf

[7] Costa, A.A., Guilhem, D. and Walter, M.I.M.T. (2005) Atendimento a gestantes no Sistema Único de Saúde. Revista de Saúde Pública, 39, 768-774. http://www.scielosp.org/pdf/rsp/v39n5/26297.pdf

http://dx.doi.org/10.1590/S0034-89102005000500011

[8] Guerreiro, E.M., Rodrigues, D.P., Silveira, M.A.M. and Lucena, N.B.F. (2012) O cuidado pré-natal na atenção básica de saúde sob o olhar de gestantes e enfermeiros. remE—Rev. Min. Enferm, 16, 315-323. http://reme.org.br/artigo/detalhes/533

[9] Brasil. Ministério da Saúde. Secretaria de Atenção à Saúde. Departamento de Ações Programáticas Estratégicas (2005) Área Técnica de Saúde da Mulher. Pré-natal e Puerpério: Atenção qualificada e humanizada—manual técnico—Brasília: Ministério da Saúde, 158 p. http://bvsms.saude.gov.br/bvs/publicacoes/pre-natal puerperio atencao humanizada.pdf

[10] Boccolini, C.S., Carvalho, M.L., Oliveira, M.I.C. and Vasconcellos, A.G.G. (2011) Fatores associados à amamentação na primeira hora de vida. Revista de Saúde Pública, 45, 69-78. http://www.scielosp.org/pdf/rsp/v45n1/1717 http://dx.doi.org/10.1590/S0034-89102010005000051

[11] Brasil. Ministério da Saúde (2009) Saúde da criança: Nutrição Infantil aleitamento materno e alimentação complementar. Cadernos de Atenção Básica, n. 23. Brasília, DF. http://bvsms.saude.gov.br/bvs/publicacoes/saude_crianca_nutricao_aleitamento_alimentacao.pdf

[12] Vieira, S.M., Bock, L.F., Zocche, D.A. and Pessota, C.U. (2011) Percepção das puérperas sobre a assistência prestada pela equipe de saúde no pré-natal. Texto Contexto-Enferm, 20, 255-262. [Online] 
http://www.scielo.br/pdf/tce/v20nspe/v20nspea32.pdf

[13] Almeida, S.D.M. and Barros, M.B.A. (2005) Equidade e atenção à saúde da gestante em Campinas (SP), Brasil. Revista Panamericana de Salud Pública, 17, 15-25. [Online] http://www.scielosp.org/pdf/rpsp/v17n1/24024.pdf http://dx.doi.org/10.1590/S1020-49892005000100003 
Scientific Research Publishing (SCIRP) is one of the largest Open Access journal publishers. It is currently publishing more than 200 open access, online, peer-reviewed journals covering a wide range of academic disciplines. SCIRP serves the worldwide academic communities and contributes to the progress and application of science with its publication.

Other selected journals from SCIRP are listed as below. Submit your manuscript to us via either submit@scirp.org or Online Submission Portal.
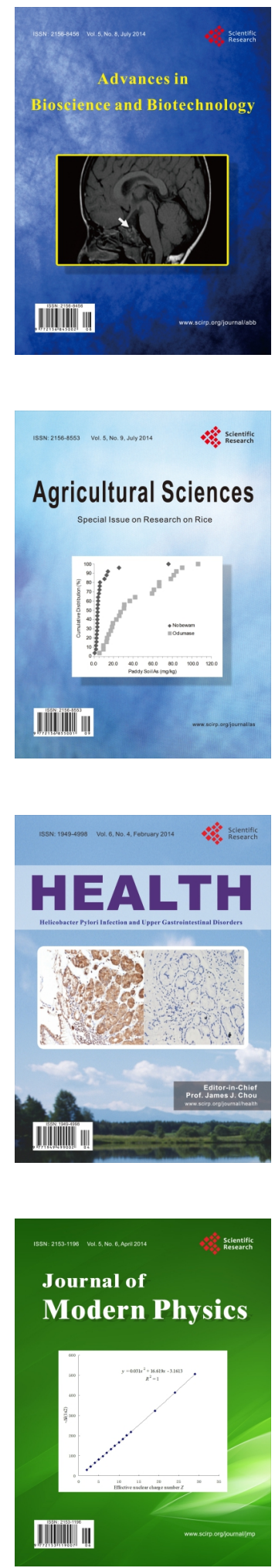
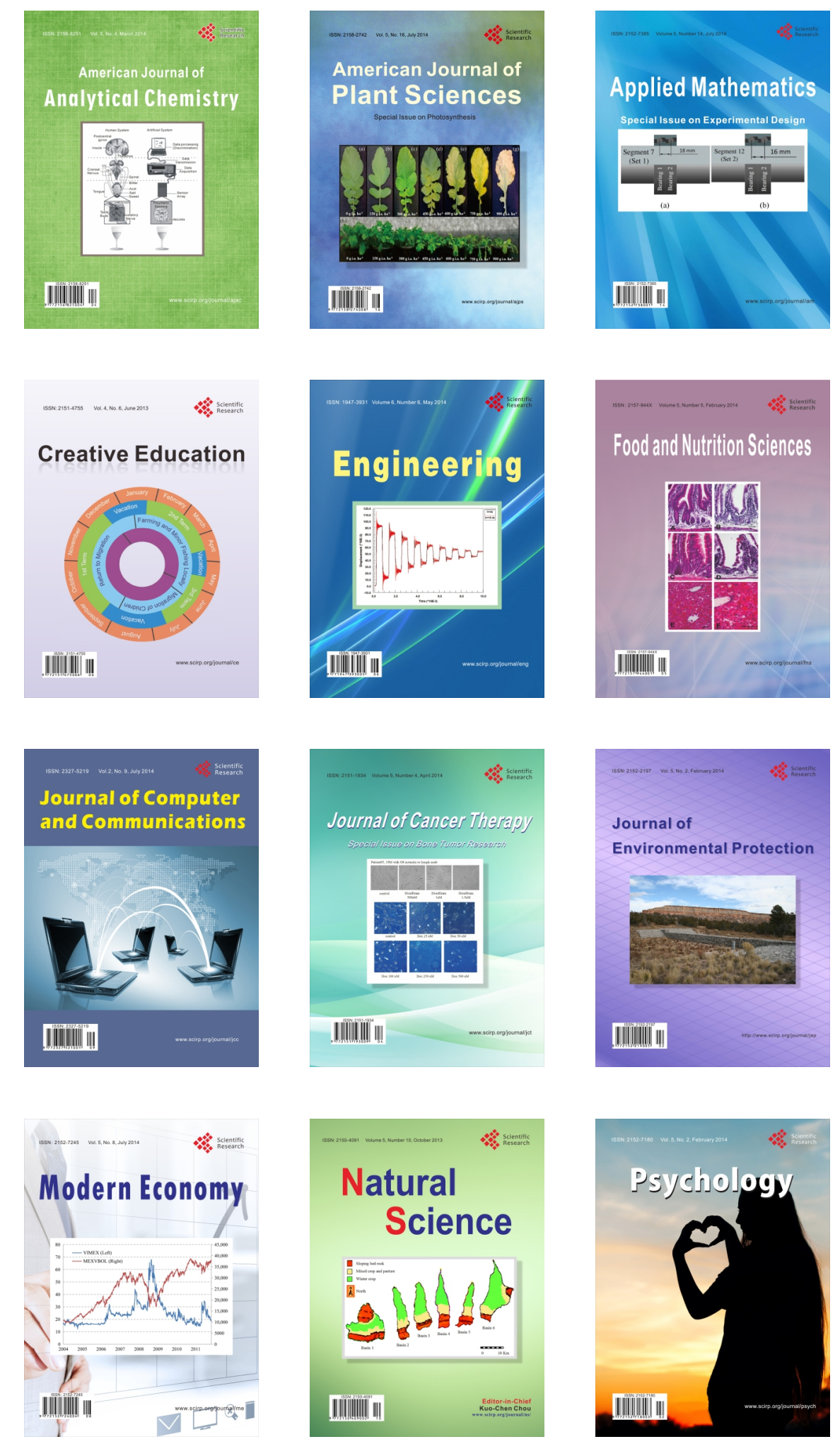